\title{
Investigation of bispidines as the stoichiometric ligand in the two- ligand catalytic asymmetric deprotonation of $N$-Boc pyrrolidine
}

\author{
Graeme Barker, ${ }^{\mathrm{a}}$ Peter O’Brien ${ }^{\mathrm{a}}$ and Kevin R. Campos ${ }^{\mathrm{b}}$ \\ ${ }^{a}$ Department of Chemistry, University of York, Heslington, York YO10 5DD, UK \\ ${ }^{b}$ Department of Process Research, Merck Research Laboratories, Rahway, New Jersey 07065 , \\ USA \\ E-mail:peter.obrien@york.ac.uk
}

\section{Dedicated to William F. Bailey on the occasion of his $65^{\text {th }}$ anniversary}

\begin{abstract}
A range of achiral bispidines have been synthesized and evaluated as the stoichiometric ligand in the two-ligand catalytic asymmetric deprotonation of $N$-Boc pyrrolidine.
\end{abstract}

Keywords: Asymmetric synthesis, organolithium reagents, (-)-sparteine, nitrogen heterocycles

\section{Introduction}

Organolithium/chiral diamine complexes are now established as versatile and useful reagents for the asymmetric synthesis of chiral molecules. ${ }^{1,2}$ In this context, (-)-sparteine is the most widelyinvestigated diamine ${ }^{3}$ following the pioneering work by Hoppe ${ }^{4}$ and Beak. ${ }^{5}$ Indeed, reagents comprising organolithium reagents (e.g. $s$-BuLi or $n$-BuLi) and (-)-sparteine have been used for the asymmetric synthesis of a diverse range of compounds including amines, ${ }^{6}$ alcohols, ${ }^{7}$ phosphines, ${ }^{8}$ ferrocenes ${ }^{9}$ and paracyclophanes. ${ }^{10}$ An example from Bailey and Mealy ${ }^{11,12}$ is representative of the synthetic potential afforded by organolithium/(-)-sparteine reagents. Treatment of di-allylated bromoaniline 1 with $t$-BuLi/(-)-sparteine 3 followed by incubation at $40{ }^{\circ} \mathrm{C}$ and quenching with $\mathrm{MeOH}$ delivered chiral indoline $(R)-2$ in 69\% yield and 93:7 er (Scheme 1). The reaction proceeds via bromine-lithium exchange and subsequent intramolecular carbolithiation in which the facial attack onto the alkene is controlled by coordination of (-)sparteine to the aryllithium intermediate. 


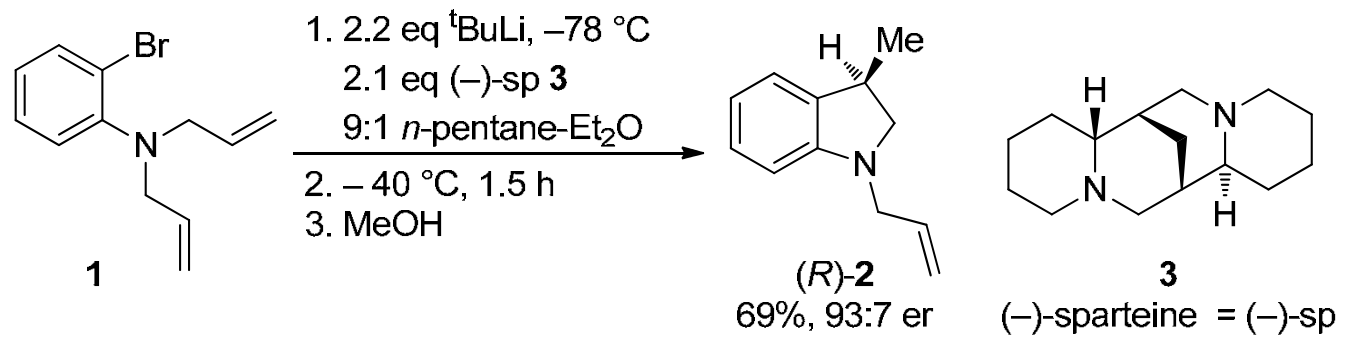

\section{Scheme 1}

Our interest in organolithium/(-)-sparteine reagents has focused on their use in the asymmetric deprotonation of $N$-Boc heterocycles. Such asymmetric reactions were first reported by Kerrick and Beak in 1991.,13 The contributions to this area from our group have included the development of effective (+)-sparteine surrogates, ${ }^{14-16}$ the introduction of two-ligand catalytic asymmetric deprotonation protocols, ${ }^{17-20}$ the high yielding asymmetric deprotonation of $N$-Boc piperidine $^{21}$ and the introduction of a diamine-free lithiation method. ${ }^{22}$

Two examples of the asymmetric deprotonation of $N$-Boc pyrrolidine 4 using substoichiometric amounts of chiral diamine are shown in Scheme 2. Thus, lithiation of $N$-Boc pyrrolidine 4 with 1.6 eq. $s$-BuLi, 0.3 eq. (-)-sparteine 3 and 1.3 eq. bis- $i$-Pr-bispidine 6 and trapping with $\mathrm{Me}_{3} \mathrm{SiCl}$ gave silyl adduct $(S)-5$ in 70\% yield and 95:5 er. ${ }^{19}$ If bis- $i$-Pr-bispidine 6 was omitted from the reaction then there was no turn-over of the $(-)$-sparteine ligand and poor yield and poor enantioselectivity results. ${ }^{13,17}$ Interestingly, we have found that $(+)$-sparteine surrogate 7 can be used in lower loadings than (-)-sparteine to achieve essentially the same level of enantioselectivity. For example, use of 1.3 eq. $s$-BuLi, 0.2 eq. (+)-sparteine surrogate 7 and 1.2 eq. bis- $i$-Pr-bispidine 6 gave silyl adduct $(R)-5$ in $66 \%$ yield and 94:6 er. It is known ${ }^{18}$ that $s$ $\mathrm{BuLi} /(+)$-sparteine surrogate 7 lithiates $N$-Boc pyrrolidine 4 faster than $s$-BuLi/(-)-sparteine 3 and we believe that this facilitates more efficient catalytic turn-over.
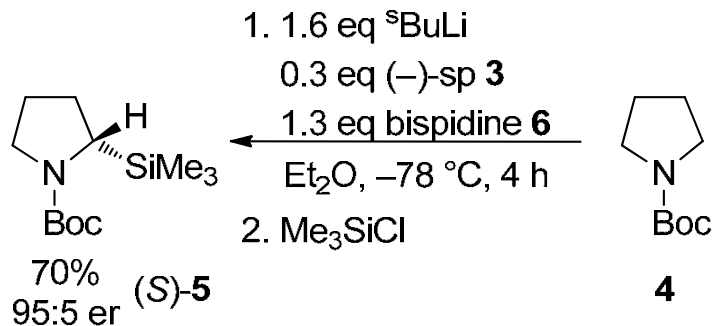

1. 1.3 eq ${ }^{\mathrm{s} B u L i}$

\section{2 eq 7}

$\underset{\substack{\mathrm{Et}_{2} \mathrm{O},-78^{\circ} \mathrm{C}, 5 \mathrm{~h}}}{\stackrel{1.2 \text { eq bispidine 6 }}{\mathrm{Me} \mathrm{SiCl}}} \overbrace{\substack{\mathrm{B} \\ \mathrm{Boc}}} \mathrm{SiMe}_{3}$

95:5 er

4

$(R)-5 \begin{gathered}66 \% \\ 94: 6 \text { er }\end{gathered}$

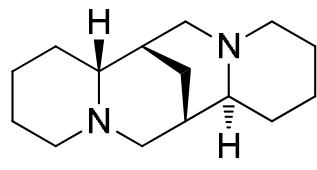

3

$(-)$-sparteine $=(-)$-sp

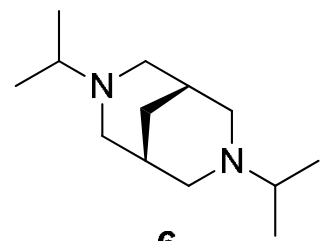

6<smiles>CN1CC2C[C@@H]3CCCCN3C[C@H]2C1</smiles>

7

$(+)$-sparteine surrogate

Scheme 2 
In both of the examples shown in Scheme 2, success was achieved using a designed recycling diamine, bis- $i$-Pr-bispidine 6. The idea was that the steric hindrance in $s$-BuLi/bispidine 6 would lead to slow lithiation of $N$-Boc pyrrolidine 4 . However, despite the steric hindrance of bispidine 6, we hoped that it would participate in ligand exchange and thus recycle the chiral diamine. The successful examples of two-ligand catalysis supported our conjecture. Unfortunately, as disclosed in our original report, bispidine 6 was prepared in a disappointing $26 \%$ yield via a known ${ }^{23}$ two-step route. As a result, we screened several other diamines in an attempt to find a recycling diamine that was easier to synthesise ${ }^{19}$ and ultimately concluded that the bispidine framework exemplified by 6 was optimum. Hence, in this paper, we present our efforts at identifying an alternative recycling bispidine ligand to bispidine $\mathbf{6}$.

\section{Results and Discussion}

To start with, a range of different bispidines was prepared as outlined in Scheme 3. A double Mannich reaction using freshly distilled $N$-i-Pr-piperidone 8, $i$-propylamine and formaldehyde gave bispidone 10 in $67 \%$ yield ( $21 \mathrm{~g}$ scale of product, purified by fractional distillation). In the same way, the $n$-Pr analogue 11 was prepared in 44\% yield from $N$ - $n$-Pr-piperidone 9 and $n$ propylamine. Our plan was to investigate different methodology for removing or masking the carbonyl functionality in bispidone 10. A Wittig reaction using the ylid from $\mathrm{Ph}_{3} \mathrm{PMe}^{+} \mathrm{Br}^{-}$ required some optimisation. Eventually, it was found that use of KHMDS as the base and refluxing for 16 hours delivered alkene 12 in 65\% yield. Subequent hydrogenation of alkene 12 using $\mathrm{NH}_{4}{ }^{+} \mathrm{HCO}_{2}{ }^{-}$and $\mathrm{Pd}(\mathrm{OH})_{2} / \mathrm{C}$ gave bispidine 13 in $65 \%$ yield. The ketone in bispidone 10 was readily reduced using $\mathrm{NaBH}_{4}$ to give alcohol 14 (69\% yield).

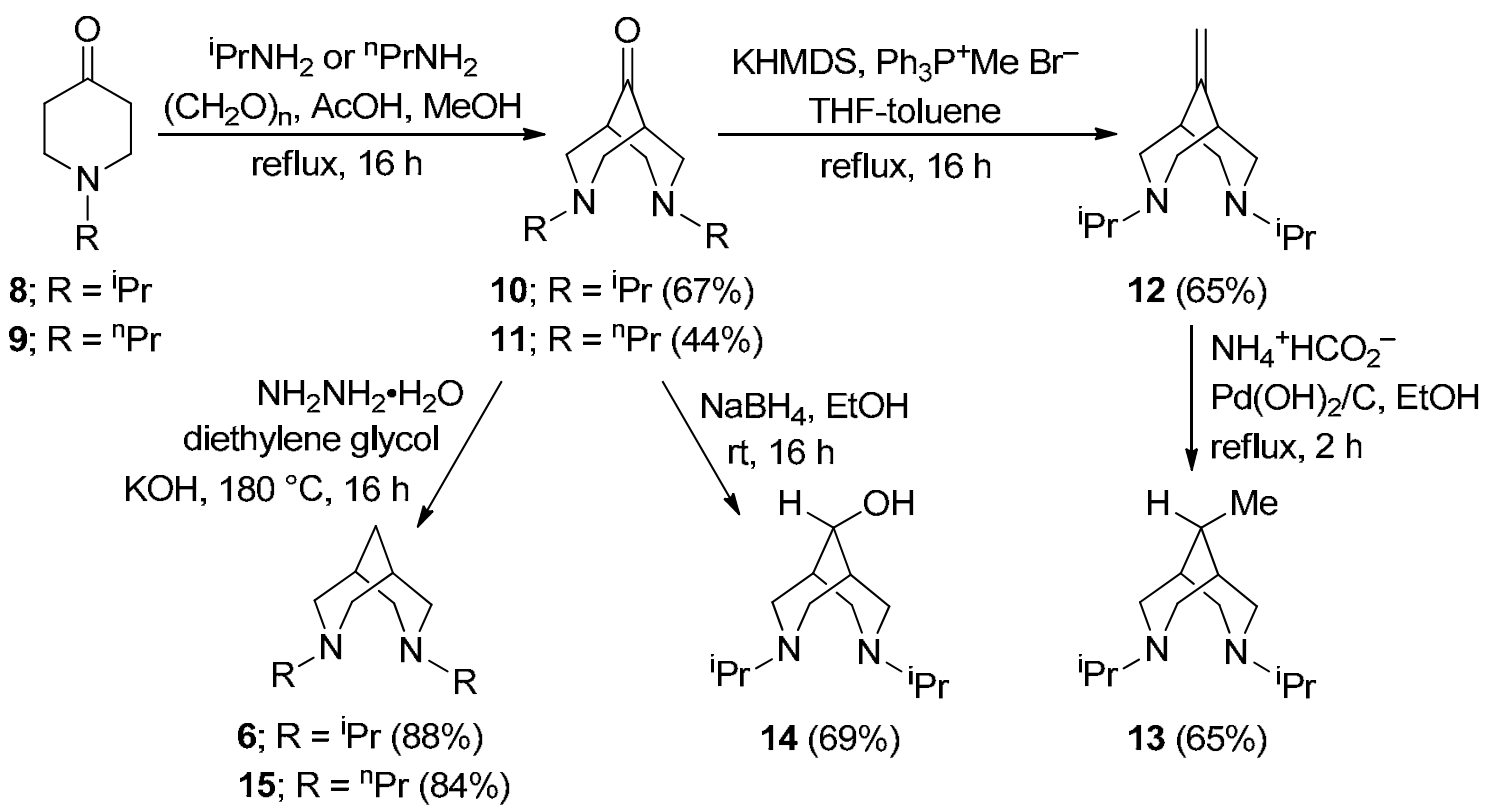

\section{Scheme 3}


Finally, as part of this study, we re-evaluated the Wolff-Kishner reduction of bispidone 10 to bis- $i$-Pr-bispidine 6. In our reported method, reaction with hydrazine/KOH was carried out at 180 ${ }^{\circ} \mathrm{C}$ for 4 hours. ${ }^{17}$ It transpired that the reaction was incomplete after 4 hours and a simple change to a reaction time of 16 hours led to a significant improvement in yield (88\% compared to $38 \%$ ). In addition, during the work-up, it was necessary to cool the reaction mixture to $\sim 60{ }^{\circ} \mathrm{C}$ and transfer it to a separating funnel and then add water. If the diethylene glycol solution was cooled to room temperature before addition of water then the reaction mixture became very viscous and difficult to work with. The bis- $n$-Pr-bispidine 15 was prepared in $84 \%$ yield in the same way.

Ultimately, none of the newly prepared analogues of bis-i-Pr-bispidine 6 were easier to synthesise than 6 itself. However, we were curious to see whether the other bispidines 12-14 would also perform satisfactorily in the two-ligand catalytic asymmetric deprotonation of $N$-Boc pyrrolidine 4. In addition, using bis- $n$-Pr-bispidine 15, it would be possible to establish whether steric hindrance on the two nitrogen atoms was required for effective two-ligand catalysis. In order to evaluate the two-ligand catalysis, we utilized the lithiation-benzaldehyde trapping ${ }^{20}$ of $N$-Boc pyrrolidine $\mathbf{4} \rightarrow$ hydroxy pyrrolidines $s y n-\mathbf{1 6}$ and anti-17, which can be separated by chromatography (Scheme 4 and Table 1). As a point of reference, a stoichiometric reaction using 1.3 eq. $s$-BuLi/(-)-sparteine 3 was carried out and delivered syn-16 (62\% yield, 97:3 er) together with anti-17 (18\% yield, 97:3 er) (entry 1). Using 1.6 eq. $s$-BuLi, 0.3 eq. (-)-sparteine 3 and 1.3 eq. bis-i-Pr-bispidine 6 gave syn-16 (91:9 er) in 62\% yield and anti-17 (91:9 er) in 33\% yield (entry 2) indicating successful two-ligand catalytic deprotonation. Slightly lower enantioselectivity (88:12 er) was observed using 1.0 eq. $s$-BuLi, 0.25 eq. (-)-sparteine 3 and 1.0 eq. bis- $i$-Pr-bispidine 6 (entry 4). Under comparable conditions, the $(+)$-sparteine surrogate 7 engendered higher enantioselectivity (94:6 er, entry 3 and 93:7 er, entry 5) in the expected opposite sense. This confirms that (+)-sparteine surrogate 7 is a better catalyst than $(-)$-sparteine 3 , probably due to a higher reactivity of the $s-\mathrm{BuLi} / 7$ complex.

Next, we investigated the use of new bis- $i$-Pr-bispidines 12, 13 and 14 as the stoichiometric recycling ligand. Use of alkene bispidine 12 (1.3 eq.) with 0.3 eq. (-)-sparteine led to comparable results to those obtained using bis- $i$-Pr-bispidine 6: the reaction gave $s y n-\mathbf{1 6}$ (61\% yield, 92:8 er) and anti-17 (30\% yield, 88:12 er) (entry 6). In contrast, methyl bispidine 13, which is structurally very similar to bis- $i$-Pr-bispidine 6, was far less successful giving syn-16 in 79:21 er and anti-17 in 78:22 er (entry 7). It is not clear why methyl bispidine $\mathbf{1 3}$ performed so poorly, although there may be subtle conformational differences between methyl bispidine $\mathbf{1 3}$ and bis- $i$-Pr-bispidine $\mathbf{6}$. A similarly low level of enantioinduction was observed with the lithium alkoxide derived from bispidol 14 (formed in situ with an extra equivalent of $s$-BuLi) (entry 8).

The importance of the $i$-propyl groups in bis- $i$-Pr-bispidine 6 was shown by the essentially racemic products (syn-16, 55:45 er; anti-17, 55:45 er) generated from the reaction using bis- $n$-Prbispidine 15 (entry 9). Clearly, in this case, the background deprotonation using $s$-BuLi/bis- $n$ Pr-bispidine 15 is competitive with deprotonation using $s$-BuLi/(-)-sparteine 3 and essentially no enantioselectivity results. Finally, we also investigated two-ligand catalysis using the Alexakis diamine $(R, R)-\mathbf{1 8}^{16,24}(0.3$ eq.) and bis-i-Pr-bispidine 6. This gave a slightly disappointing result 
with syn-16 and anti-17 being formed in 84:16 er and 85:15 er respectively (entry 10). Clearly, the bispidine chiral ligands, (-)-sparteine 3 and $(+)$-sparteine surrogate 7 , in tandem with bis- $i$ Pr-bispidine 6 are optimal for these types of two-ligand catalytic asymmetric deprotonations.

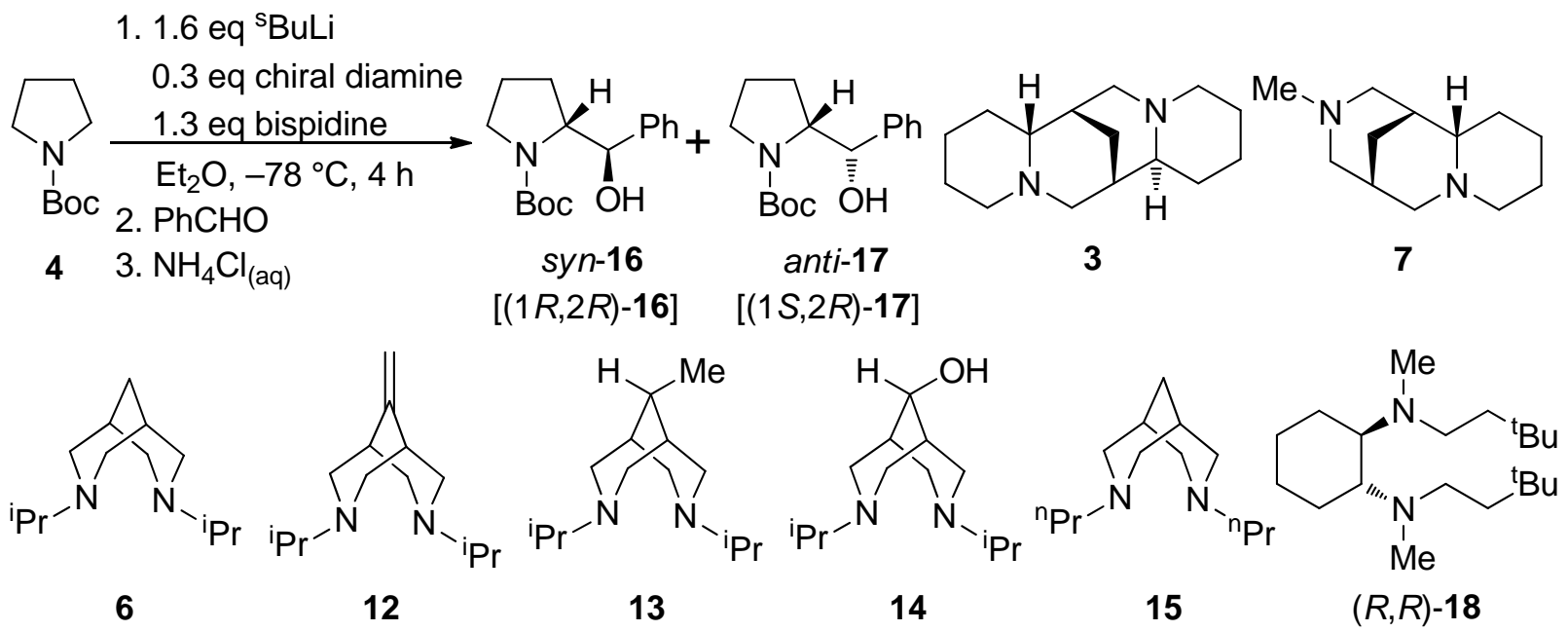

\section{Scheme 4}

Table 1

\begin{tabular}{|c|c|c|c|c|c|c|}
\hline Entry & $\begin{array}{l}\text { Chiral } \\
\text { diamine }\end{array}$ & Bispidine & $\begin{array}{l}\text { Yield (\%) } \\
\text { of } s y n-16^{\mathrm{b}}\end{array}$ & $\begin{array}{c}\text { er of } \\
\text { syn-16 }\end{array}$ & $\begin{array}{c}\text { Yield (\%) } \\
\text { of anti-17 }\end{array}$ & $\begin{array}{c}\text { er of } \\
\text { anti-17 }^{\mathrm{c}}\end{array}$ \\
\hline 1 & $3^{\mathrm{a}}$ & - & 62 & $97: 3$ & 18 & $97: 3$ \\
\hline 2 & 3 & 6 & 62 & 91:9 & 33 & 91:9 \\
\hline 3 & 7 & 6 & 65 & $6: 94^{d}$ & 29 & $6: 94^{d}$ \\
\hline 4 & $3^{\mathrm{e}}$ & $6^{\mathrm{e}}$ & 58 & $88: 12$ & 29 & $88: 12$ \\
\hline 5 & $7^{e}$ & $6^{\mathrm{e}}$ & 56 & $7: 93^{d}$ & 25 & $7: 93^{d}$ \\
\hline 6 & 3 & 12 & 61 & $92: 8$ & 30 & $88: 12$ \\
\hline 7 & 3 & 13 & 60 & $79: 21$ & 32 & $78: 22$ \\
\hline 8 & 3 & $14^{\mathrm{f}}$ & 54 & $83: 17$ & 31 & $77: 23$ \\
\hline 9 & 3 & 15 & 61 & $55: 45$ & 34 & $55: 45$ \\
\hline 10 & $(R, R)-\mathbf{1 8}$ & 6 & 63 & $84: 16$ & 27 & $85: 15$ \\
\hline
\end{tabular}

${ }^{a}$ Stoichiometric (-)-sparteine conditions: 1.3 eq. $s$-BuLi and 1.3 eq. (-)-sparteine 3 used. ${ }^{b}$ Yield after purification by column chromatography. ${ }^{c}$ Enantiomer ratio (er) determined by CSP-HPLC. ${ }^{\mathrm{d}}$ Opposite enantiomer of $s y n-\mathbf{1 6}$ and anti-17 obtained as the major product. ${ }^{\mathrm{e}} 1.0$ eq. $s$-BuLi, 0.25 eq. chiral diamine and 1.0 eq. bispidine used. ${ }^{\mathrm{f}} \mathrm{An}$ additional 1.3 eq. $s$-BuLi was used to deprotonate the hydroxyl group. 


\section{Conclusion}

In conclusion, we have optimised the two-step synthesis of bis- $i$-Pr-bispidine 6 and carried out the synthesis of other bispidines for use in the two-ligand catalytic asymmetric deprotonation of $N$-Boc pyrrolidine 4. Although alkene bispidine 12 worked well, we believe that bis- $i$-Prbispidine 6 remains the best stoichiometric recycling diamine for such catalytic asymmetric deprotonation reactions.

\section{Experimental Section}

General. $\mathrm{H}_{2} \mathrm{O}$ is distilled water. Brine refers to a saturated aqueous solution of $\mathrm{NaCl}$. $\mathrm{Et}_{2} \mathrm{O}$, THF or Methyl-THF were freshly distilled from sodium and benzophenone ketyl. All diamines and $\mathrm{N}$ Boc pyrrolidine were distilled over $\mathrm{CaH}_{2}$ before use. Petrol refers to the fraction of petroleum ether boiling in the range $40-60{ }^{\circ} \mathrm{C}$. All reactions were carried out under $\mathrm{O}_{2}$-free Ar using ovendried and/or flame-dried glassware. $n$-Butyllithium and $s$-butyllithium were titrated against $N$ benzylbenzamide before use. ${ }^{25}$

Flash column chromatography was carried out using Fluka Chemie GmbH silica (220-440 mesh). Thin layer chromatography was carried out using Merck $\mathrm{F}_{254}$ aluminium-backed silica plates. ${ }^{1} \mathrm{H}(400 \mathrm{MHz})$ and ${ }^{13} \mathrm{C}(100.6 \mathrm{MHz})$ NMR spectra were recorded on a Jeol ECX-400 instrument with an internal deuterium lock. Chemical shifts are quoted as parts per million and referenced to $\mathrm{CHCl}_{3}\left(\delta_{\mathrm{H}} 7.27\right)$ and or $\mathrm{CDCl}_{3}\left(\delta_{\mathrm{C}} 77.0\right.$, central line of triplet). ${ }^{13} \mathrm{C}$ NMR spectra were recorded with broadband proton decoupling. ${ }^{13} \mathrm{C}$ NMR spectra were assigned using DEPT experiments. Coupling constants $(J)$ are quoted in Hertz. IR spectra were recorded on an ATI Matteson Genesis FT-IR spectrometer. Boiling points given for compounds purified by Kügelrohr distillation correspond to the oven temperature during distillation. Electrospray high and low resolution mass spectra were recorded on a Bruker Daltronics microOTOF spectrometer. Optical rotations were recorded at room temperature on a Jasco DIP-370 polarimeter (using sodium D line; $259 \mathrm{~nm}$ ) and $[\alpha]_{\mathrm{D}}$ given in units of $10^{-1} \mathrm{deg}^{3} \mathrm{~cm}^{-1}$. Chiral stationary phase (CSP)-HPLC was performed on an Agilent 1200 series instrument and a multiple wavelength, $\mathrm{UV} / \mathrm{Vis}$ diode array detector; integration was normally performed at $230 \mathrm{~nm}$.

\section{General procedure for two-ligand deprotonation of $\boldsymbol{N}$-Boc pyrrolidine (4)}

$s$-BuLi (1.3 M solution in hexanes, 1.0 or 1.6 eq.) was added dropwise to a stirred solution of chiral diamine ( 0.2 or 0.3 eq.) and bispidine ( 1.0 or 1.3 eq.) in $\mathrm{Et}_{2} \mathrm{O}(6 \mathrm{~mL})$ at $-78{ }^{\circ} \mathrm{C}$ under $\mathrm{Ar}$. After stirring at $-78{ }^{\circ} \mathrm{C}$ for $15 \mathrm{~min}$, a solution of $N$-Boc pyrrolidine $4(230 \mathrm{mg}, 235 \mu \mathrm{L}, 1.34$ mmol, 1.0 eq.) in $\mathrm{Et}_{2} \mathrm{O}(1 \mathrm{~mL})$ was added dropwise. The resulting pale yellow solution was stirred at $-78{ }^{\circ} \mathrm{C}$ for $4 \mathrm{~h}$. Then, benzaldehyde ( $282 \mathrm{mg}, 270 \mu \mathrm{L}, 2.68 \mathrm{mmol}, 2$ eq.) was added and the resulting solution was allowed to warm to rt over $16 \mathrm{~h}$. Saturated $\mathrm{NH}_{4} \mathrm{Cl}_{(\mathrm{aq})}(10 \mathrm{~mL})$ was added and the layers were separated. The aqueous layer was extracted with $\mathrm{Et}_{2} \mathrm{O}(3 \times 10 \mathrm{~mL})$ and 
the combined organic layers were dried $\left(\mathrm{MgSO}_{4}\right)$ and evaporated under reduced pressure to give the crude product.

3,7-Diisopropyl-3,7-diazabicyclo[3.3.1]nonan-9-one (10). $i$-Propylamine $(12.2 \mathrm{~mL}, 142.0$ mmol) was added dropwise to a stirred solution of $N$-i-propyl-4-piperidone $8(21.1 \mathrm{~mL}, 142.0$ mmol, freshly distilled), paraformaldehyde (12.78 g, $426.0 \mathrm{mmol})$ and $\mathrm{AcOH}(8.46 \mathrm{~mL}, 148.0$ $\mathrm{mmol})$ in $\mathrm{MeOH}(200 \mathrm{~mL})$ at $\mathrm{rt}$ under Ar. The resulting solution was stirred and heated at reflux for $16 \mathrm{~h}$. The solvent was evaporated under reduced pressure. Then, $50 \% \mathrm{w} / \mathrm{v} \mathrm{KOH}_{(\mathrm{aq})}$ solution $(500 \mathrm{~mL})$ and $\mathrm{Et}_{2} \mathrm{O}(500 \mathrm{~mL})$ were added to the residue and the layers were separated. The aqueous layer was extracted with $\mathrm{Et}_{2} \mathrm{O}(2 \times 500 \mathrm{~mL})$ and the combined organic layers were dried $\left(\mathrm{Na}_{2} \mathrm{SO}_{4}\right)$ and evaporated under reduced pressure to give the crude product. Purification by fractional distillation gave bispidone $10(21.39 \mathrm{~g}, 67 \%)$ as a colourless oil, bp $128-130{ }^{\circ} \mathrm{C} / 2.0$ mmHg (lit., ${ }^{23}$ bp 110-120 ${ }^{\circ} \mathrm{C} / 10^{-5} \mathrm{mmHg}$ ); ${ }^{1} \mathrm{H} \mathrm{NMR}\left(400 \mathrm{MHz}, \mathrm{CDCl}_{3}\right) \delta 3.01$ (dd, $J 10.5,3.0$ $\left.\mathrm{Hz}, 4 \mathrm{H}, \mathrm{NCH}_{\mathrm{A}} \mathrm{H}_{\mathrm{B}}\right), 2.86\left(\mathrm{dd}, J 10.5,7.0 \mathrm{~Hz}, 4 \mathrm{H}, \mathrm{NCH}_{\mathrm{A}} H_{\mathrm{B}}\right), 2.85-2.76$ (m, 2H, NCH), 2.61-2.54 (m, 2H, COCH), 0.99 (d, J $6.5 \mathrm{~Hz}, 12 \mathrm{H}, \mathrm{Me})$. Spectroscopic data consistent with those reported in the literature. ${ }^{23}$

3,7-Di-n-propyl-3,7-diazabicyclo[3.3.1]nonan-9-one (11). $n$-Propylamine (5.83 mL, 70.81 mmol) was added dropwise to a stirred solution of $N$-n-propyl-4-piperidone $9(10.7 \mathrm{~mL}, 10 \mathrm{~g}$, $70.81 \mathrm{mmol})$, paraformaldehyde $(6.38 \mathrm{~g}, 212.4 \mathrm{mmol})$ and $\mathrm{AcOH}(4.22 \mathrm{~mL}, 73.8 \mathrm{mmol})$ in $\mathrm{MeOH}(100 \mathrm{~mL})$ at $\mathrm{rt}$ under Ar. The resulting solution was stirred and heated at reflux for $16 \mathrm{~h}$. The solvent was evaporated under reduced pressure. Then, $50 \% \mathrm{KOH}_{(\mathrm{aq})}$ solution $(250 \mathrm{~mL})$ and $\mathrm{Et}_{2} \mathrm{O}(250 \mathrm{~mL})$ were added to the residue and the layers were separated. The aqueous layer was extracted with $\mathrm{Et}_{2} \mathrm{O}(2 \times 250 \mathrm{~mL})$ and the combined organic layers were dried $\left(\mathrm{Na}_{2} \mathrm{SO}_{4}\right)$ and evaporated under reduced pressure to give the crude product. Purification by fractional distillation gave bispidone 11 (7.01 g, 44\%) as a yellow oil, bp 95-100 ${ }^{\circ} \mathrm{C} / 0.2 \mathrm{mmHg}$; IR (film) 2958, $1739(\mathrm{C}=\mathrm{O}), 1469,1359,1208,1137,1087,1036,735 \mathrm{~cm}^{-1} ;{ }^{1} \mathrm{H} \mathrm{NMR}\left(400 \mathrm{MHz}, \mathrm{CDCl}_{3}\right)$ $\delta 2.99\left(\mathrm{dd}, J 11.0,2.0 \mathrm{~Hz}, 4 \mathrm{H}, \mathrm{NCH}_{\mathrm{A}} \mathrm{H}_{\mathrm{B}}\right), 2.79\left(\mathrm{dd}, J 11.0,6.5 \mathrm{~Hz}, 4 \mathrm{H}, \mathrm{NCH}_{\mathrm{A}} H_{\mathrm{B}}\right), 2.56($ br s, $2 \mathrm{H}, \mathrm{COCH}), 2.31\left(\mathrm{t}, J 7.5 \mathrm{~Hz}, 4 \mathrm{H}, \mathrm{NCH}_{2} \mathrm{CH}_{2}\right), 1.50-1.40\left(\mathrm{~m}, 4 \mathrm{H}, \mathrm{NCH}_{2} \mathrm{CH}_{2}\right), 0.89$ (t, J 7.5 Hz, $6 \mathrm{H}, \mathrm{Me}) ;{ }^{13} \mathrm{C} \mathrm{NMR}\left(100.6 \mathrm{MHz}, \mathrm{CDCl}_{3}\right) \delta 215.1(\mathrm{C}=\mathrm{O}), 58.5\left(\mathrm{NCH}_{2}\right), 58.4\left(\mathrm{NCH}_{2}\right), 46.6$ (CHCO), $20.3\left(\mathrm{CH}_{2} \mathrm{Me}\right), 11.8(\mathrm{Me})$; MS (ESI) $m / z 257\left[(\mathrm{M}+\mathrm{MeOH}+\mathrm{H})^{+}, 100\right], 225\left[(\mathrm{M}+\mathrm{H})^{+}\right.$, 1]; HRMS (ESI) $m / z$ calcd for $\mathrm{C}_{14} \mathrm{H}_{24} \mathrm{~N}_{2} \mathrm{O}(\mathrm{M}+\mathrm{H})^{+} 225.1961$, found 225.1970 (3.7 ppm error); $m / z$ calcd for $\mathrm{C}_{14} \mathrm{H}_{24} \mathrm{~N}_{2} \mathrm{O}(\mathrm{M}+\mathrm{MeOH}+\mathrm{H})^{+} 257.2224$, found 257.2220 (1.3 ppm error).

3,7-Diisopropyl-9-methylene-3,7-diazabicyclo[3.3.1]nonane (12). KHMDS (65.4 mL of a 0.5 $\mathrm{M}$ solution in toluene, $32.7 \mathrm{mmol}$ ) was added dropwise to a stirred solution of $\mathrm{MePh}_{3} \mathrm{P}^{+} \mathrm{Br}^{-}$ $(11.68 \mathrm{~g}, 32.7 \mathrm{mmol})$ in THF $(240 \mathrm{~mL})$ at $0{ }^{\circ} \mathrm{C}$ under Ar. After stirring at $0{ }^{\circ} \mathrm{C}$ for $30 \mathrm{~min}$, a solution of bispidone $10(7.00 \mathrm{~g}, 31.2 \mathrm{mmol})$ in THF $(60 \mathrm{~mL})$ was added dropwise. The resulting solution was stirred at $0{ }^{\circ} \mathrm{C}$ for $15 \mathrm{~min}$ and then stirred and heated at reflux for $16 \mathrm{~h}$. The solvent was evaporated under reduced pressure and $5 \mathrm{M} \mathrm{HCl}_{(\mathrm{aq})}$ solution $(250 \mathrm{~mL})$ was added to the residue. The aqueous solution washed with $\mathrm{CH}_{2} \mathrm{Cl}_{2}(2 \times 500 \mathrm{~mL})$ and then basified to $\mathrm{pH} 14$ by addition of $5 \mathrm{M} \mathrm{NaOH}_{(\mathrm{aq})}$. The aqueous solution was stirred at $\mathrm{rt}$ for $1 \mathrm{~h}$ and then extracted with $\mathrm{Et}_{2} \mathrm{O}(8 \times 200 \mathrm{~mL})$. The combined organic extracts were dried $\left(\mathrm{Na}_{2} \mathrm{SO}_{4}\right)$ and evaporated under 
reduced pressure to give the crude product as a yellow oil. Purification by Kügelrohr distillation gave alkene bispidine 12 (4.48 g, 65\%) as a colourless oil, bp 120-130 ${ }^{\circ} \mathrm{C} / 1.2 \mathrm{mmHg}$; IR (film) 3069, 2931, $1670(\mathrm{C}=\mathrm{C}), 1469,1386,1358,1176,880 \mathrm{~cm}^{-1} ;{ }^{1} \mathrm{H} \mathrm{NMR}\left(400 \mathrm{MHz}, \mathrm{CDCl}_{3}\right) \delta 4.67$ $\left(\mathrm{s}, 2 \mathrm{H}, \mathrm{C}=\mathrm{CH}_{2}\right), 2.78-2.68(\mathrm{~m}, 2 \mathrm{H}, \mathrm{NCH}), 2.68-2.60\left(\mathrm{~m}, 8 \mathrm{H}, \mathrm{NCH}_{2}\right), 2.58-2.40(\mathrm{~m}, 2 \mathrm{H}$, $\left.\mathrm{NCH}_{2} \mathrm{CH}\right), 0.99(\mathrm{~d}, J 6.5 \mathrm{~Hz}, 12 \mathrm{H}, \mathrm{Me}) ;{ }^{13} \mathrm{C} \mathrm{NMR}\left(100.6 \mathrm{MHz}, \mathrm{CDCl}_{3}\right) \delta 151.4\left(C=\mathrm{CH}_{2}\right), 104.7$ $\left(\mathrm{C}=\mathrm{CH}_{2}\right), 53.8\left(\mathrm{NCH}_{2}\right), 53.4(\mathrm{NCH}), 39.0\left(\mathrm{NCH}_{2} \mathrm{CH}\right), 18.1(\mathrm{Me})$; MS (ESI) $m / z 223\left[(\mathrm{M}+\mathrm{H})^{+}\right.$, 100], 150 (15), 123 (30); HRMS (ESI) $m / z$ calcd for $\mathrm{C}_{14} \mathrm{H}_{26} \mathrm{~N}_{2}(\mathrm{M}+\mathrm{H})^{+}$223.2169, found 223.2169 (0.3 ppm error).

3,7-Diisopropyl-9-methyl-3,7-diazabicyclo[3.3.1]nonane (13). A solution of alkene bispidine 12 (4.48 g, $20.1 \mathrm{mmol})$ and $\mathrm{NH}_{4}{ }^{+} \mathrm{HCO}_{2}{ }^{-}(4.16 \mathrm{~g}, 66.0 \mathrm{mmol})$ in EtOH (130 mL) was stirred and heated at reflux under Ar. Then, $20 \% \mathrm{Pd}(\mathrm{OH})_{2} / \mathrm{C}(1.22 \mathrm{~g}, 1.4 \mathrm{mmol})$ was added in one portion. The resulting mixture was stirred and heated at reflux for $2 \mathrm{~h}$. After cooling to rt, the resulting mixture was basified to $\mathrm{pH} 14$ by addition of $5 \mathrm{M} \mathrm{NaOH}_{(\mathrm{aq})}$ solution. The aqueous solution was stirred at $\mathrm{rt}$ for $1 \mathrm{~h}$. Then, the solids were removed by filtration through a minimum amount of Celite $^{\circledR}$ and washed with $5 \mathrm{M} \mathrm{NaOH}_{(\mathrm{aq})}$ solution $(20 \mathrm{~mL})$. The EtOH was evaporated under reduced pressure and the aqueous residue was extracted with $\mathrm{Et}_{2} \mathrm{O}(8 \times 200 \mathrm{~mL})$. The combined organic extracts were dried $\left(\mathrm{Na}_{2} \mathrm{SO}_{4}\right)$ and evaporated under reduced pressure to give the crude product as a yellow oil. Purification by Kügelrohr distillation gave methyl bispidine 13 (2.87 g, $65 \%$ ) as a colourless oil, bp 130-140 ${ }^{\circ} \mathrm{C} / 0.4 \mathrm{mmHg}$; IR (film) 2963, 2932, 1381, 1179, $1110 \mathrm{~cm}^{-}$ ${ }^{1} ;{ }^{1} \mathrm{H}$ NMR (400 MHz, $\left.\mathrm{CDCl}_{3}\right) \delta$ 2.79-2.60 (m, 8H, $\mathrm{NCH}_{2}$ ), 2.40-2.34 (m, 2H, NCH), 1.86-1.78 (m, 1H, CHMe), 1.66 (br s, 2H, $\left.\mathrm{NCH}_{2} \mathrm{CH}\right), 1.05-0.95$ (m, 15H, CHMe + $\mathrm{CHMe}_{2}$ ); ${ }^{13} \mathrm{C} \mathrm{NMR}$ $\left(100.6 \mathrm{MHz}, \mathrm{CDCl}_{3}\right) \delta 53.9(\mathrm{NCH}), 53.6(\mathrm{NCH}), 53.5\left(\mathrm{NCH}_{2}\right), 47.1\left(\mathrm{NCH}_{2}\right), 34.2(\mathrm{CH}), 30.2$ (CH), $18.2(\mathrm{Me}), 17.9(\mathrm{Me}), 16.5(\mathrm{Me})$; MS (ESI) $m / z 225\left[(\mathrm{M}+\mathrm{H})^{+}, 100\right]$; HRMS (ESI) $m / z$ calcd for $\mathrm{C}_{14} \mathrm{H}_{28} \mathrm{~N}_{2}(\mathrm{M}+\mathrm{H})^{+}$225.2325, found 225.2326 (0.4 ppm error).

3,7-Diisopropyl-3,7-diazabicyclo[3.3.1]nonan-9-ol (14). A solution of $\mathrm{NaBH}_{4}$ (37 mg, 1.0 $\mathrm{mmol})$ in $\mathrm{H}_{2} \mathrm{O}(1.5 \mathrm{~mL})$ was added dropwise to a stirred solution of bispidone $\mathbf{1 0}(200 \mathrm{mg}, 0.9$ $\mathrm{mmol})$ in $\mathrm{EtOH}(3.0 \mathrm{~mL})$ at $\mathrm{rt}$ under air. The resulting solution was stirred at $\mathrm{rt}$ for $16 \mathrm{~h}$. The EtOH was evaporated under reduced pressure and the residue was basified to $\mathrm{pH} 14$ by addition of $5 \mathrm{M} \mathrm{NaOH}_{(\mathrm{aq})}$ solution. The solution was stirred at $\mathrm{rt}$ for $1 \mathrm{~h}$ and then extracted with $\mathrm{Et}_{2} \mathrm{O}(8 \times$ $10 \mathrm{~mL})$. The combined organic extracts were dried $\left(\mathrm{Na}_{2} \mathrm{SO}_{4}\right)$ and evaporated under reduced pressure to give bispidol 14 (138 mg, 69\%) as a colourless oil, bp 170-180 ${ }^{\circ} \mathrm{C} / 5 \mathrm{mmHg}$; IR (film) $3328(\mathrm{OH}), 2965,2924,1469,1382,1360,1221,1174,1096,1069,1052 \mathrm{~cm}^{-1}$; ${ }^{1} \mathrm{H}$ NMR (400 $\left.\mathrm{MHz} \mathrm{CDCl}_{3}\right) \delta 6.06$ (br s, $\left.1 \mathrm{H}, \mathrm{OH}\right), 3.31$ (br s, $\left.1 \mathrm{H}, \mathrm{CHOH}\right), 2.99$ (br t, $J 10.5 \mathrm{~Hz}, 2 \mathrm{H}$ ), 2.72-2.62 $(\mathrm{m}, 2 \mathrm{H}), 2.62-2.42(\mathrm{~m}, 4 \mathrm{H}), 2.28-2.15(\mathrm{~m}, 4 \mathrm{H}), 0.99$ (d, J 6.5 Hz, 6H, Me), 0.94 (d, J 6.5 Hz, 6H, $\mathrm{Me}) ;{ }^{13} \mathrm{C} \mathrm{NMR}\left(100.6 \mathrm{MHz}, \mathrm{CDCl}_{3}\right) \delta 73.2(\mathrm{CHOH}), 53.3(\mathrm{NCH}), 52.9(\mathrm{NCH}), 52.4\left(\mathrm{NCH}_{2}\right)$, $48.5\left(\mathrm{NCH}_{2}\right), 34.6\left(\mathrm{NCH}_{2} \mathrm{CH}\right), 18.2(\mathrm{Me}), 18.1(\mathrm{Me})$; MS (ESI) $m / z 227$ [(M+ H) $\left.{ }^{+}, 100\right]$; HRMS (ESI) $m / z$ calcd for $\mathrm{C}_{13} \mathrm{H}_{26} \mathrm{~N}_{2} \mathrm{O}(\mathrm{M}+\mathrm{H})^{+} 227.2118$, found 227.2124 (2.9 ppm error).

3,7-Diisopropyl-3,7-diazabicyclo[3.3.1]nonane (6). Hydrazine monohydrate (6.22 mL, 127.9 mmol) was added dropwise to a stirred mixture of bispidone 10 (5.17 g, $23.0 \mathrm{mmol})$ and $\mathrm{KOH}$ $(15.1 \mathrm{~g}, 269.0 \mathrm{mmol})$ in diethylene glycol $(130 \mathrm{~mL})$ at $\mathrm{rt}$ under Ar. The resulting mixture was 
stirred and heated at $180{ }^{\circ} \mathrm{C}$ for $16 \mathrm{~h}$. After cooling to $60{ }^{\circ} \mathrm{C}$ (if the diethylene glycol solution is cooled to $\mathrm{rt}$ before addition of $\mathrm{H}_{2} \mathrm{O}$ then the mixture becomes very viscous and difficult to work with), the mixture was transferred to a separating funnel and $\mathrm{H}_{2} \mathrm{O}(155 \mathrm{~mL})$ was added. Then, $\mathrm{Et}_{2} \mathrm{O}(85 \mathrm{~mL})$ was added and the layers were separated. The aqueous layer was extracted with $\mathrm{Et}_{2} \mathrm{O}(6 \times 85 \mathrm{~mL})$ and the combined organic layers were washed with $20 \% \mathrm{NaOH}_{(\mathrm{aq})}(6 \times 100$ $\mathrm{mL}$ ), dried $\left(\mathrm{Na}_{2} \mathrm{SO}_{4}\right)$ and evaporated under reduced pressure to give bis- $i$-Pr-bispidine 6 (4.29 g, $88 \%$ ) as a colourless oil, ${ }^{1} \mathrm{H}$ NMR $\left(400 \mathrm{MHz}, \mathrm{CDCl}_{3}\right) \delta 2.68-2.57$ (m, 2H, NCH), 2.53 (dd, $J$ $10.5,5.5 \mathrm{~Hz}, 4 \mathrm{H}, \mathrm{NCH}_{2}$ ), 2.46 (br d, $J 10.5 \mathrm{~Hz}, 4 \mathrm{H}, \mathrm{NCH}_{2}$ ), 1.97-1.92 (m, 2H, $\mathrm{NCH}_{2} \mathrm{CH}$ ), 1.46$1.41\left(\mathrm{~m}, 2 \mathrm{H}, \mathrm{NCH}_{2} \mathrm{CHCH}_{2}\right), 0.97(\mathrm{~d}, J 6.5 \mathrm{~Hz}, 12 \mathrm{H}, \mathrm{NCHMe}$ ). Spectroscopic data consistent with those reported in the literature. ${ }^{17}$ Bis- $i$-Pr-bispidine 6 was purified by Kügelrohr distillation (bp $110-120^{\circ} \mathrm{C}, 0.4 \mathrm{mmHg}$ ) immediately before use.

3,7-Dipropyl-3,7-diazabicyclo[3.3.1]nonane (15). Hydrazine monohydrate (4.72 mL, 86.5 mmol) was added dropwise to a stirred mixture of bispidone 11 (3.5 g, $15.6 \mathrm{mmol})$ and $\mathrm{KOH}$ $(9.11 \mathrm{~g}, 182.0 \mathrm{mmol})$ in diethylene glycol $(90 \mathrm{~mL})$ at $\mathrm{rt}$ under Ar. The resulting mixture was stirred and heated at $180{ }^{\circ} \mathrm{C}$ for $16 \mathrm{~h}$. After cooling to $60{ }^{\circ} \mathrm{C}$ (if the diethylene glycol solution is cooled to rt before addition of $\mathrm{H}_{2} \mathrm{O}$ then the mixture becomes very viscous and difficult to work with), the mixture was transferred to a separating funnel and $\mathrm{H}_{2} \mathrm{O}(80 \mathrm{~mL})$ was added. Then, $\mathrm{Et}_{2} \mathrm{O}(60 \mathrm{~mL})$ was added and the layers separated. The aqueous layer was extracted with $\mathrm{Et}_{2} \mathrm{O}(6$ $\times 60 \mathrm{~mL})$ and the combined organic layers were washed with $20 \% \mathrm{NaOH}_{(\mathrm{aq})}(6 \times 90 \mathrm{~mL})$, dried $\left(\mathrm{Na}_{2} \mathrm{SO}_{4}\right)$ and evaporated under reduced pressure to give bis- $n$-Pr-bispidine $15(2.77 \mathrm{~g}, 84 \%)$ as a colourless oil, bp 100-110 ${ }^{\circ} \mathrm{C} / 2.0 \mathrm{mmHg}$; IR (film) 2955, 2932, 1462, 1375, 1290, 1272, 1148 , 1106, 1068, $1001 \mathrm{~cm}^{-1} ;{ }^{1} \mathrm{H}$ NMR (400 MHz, $\left.\mathrm{CDCl}_{3}\right) \delta 2.69$ (br d, $\left.J 10.5 \mathrm{~Hz}, 4 \mathrm{H}, \mathrm{NCH}_{\mathrm{A}} \mathrm{H}_{\mathrm{B}}\right), 2.28$ (dd, J 10.5, 4.5 Hz, 4H, $\left.\mathrm{NCH}_{\mathrm{A}} H_{\mathrm{B}}\right), 2.19$ (t, J 7.5 Hz, 4H, $\mathrm{NCH}_{2} \mathrm{CH}_{2}$ ), 1.91 (br s, $2 \mathrm{H}, \mathrm{NCH}_{2} \mathrm{CH}$ ), 1.52-1.41 (m, 6H, $\left.\mathrm{NCH}_{2} \mathrm{CH}_{2}+\mathrm{CH}_{2} \mathrm{CHCH}_{2}\right), 0.87$ (t, $\left.J 7.5 \mathrm{~Hz}, 6 \mathrm{H}, \mathrm{Me}\right) ;{ }^{13} \mathrm{C} \mathrm{NMR}(100.6 \mathrm{MHz}$, $\left.\mathrm{CDCl}_{3}\right) \delta 61.0\left(\mathrm{NCH}_{2}\right), 57.9\left(\mathrm{NCH}_{2}\right), 29.9$ (bridge $\left.\mathrm{CH}_{2}\right), 29.2\left(\mathrm{NCH}_{2} \mathrm{CH}\right), 20.1\left(\mathrm{NCH}_{2} \mathrm{CH}_{2}\right), 11.9$ (Me); MS (ESI) $m / z 211$ [(M + H) $\left.{ }^{+}, 100\right], 199$ (12); HRMS (ESI) $m / z$ calcd for $\mathrm{C}_{13} \mathrm{H}_{26} \mathrm{~N}_{2}(\mathrm{M}+$ H) ${ }^{+}$211.2169, found 211.2162 (3.0 ppm error).

2-(Hydroxyphenylmethyl)pyrrolidine-1-carboxylic acid tert-butyl ester $(1 R, 2 R)-16$ and (1S,2R)-17 (Table 1, entry 1). $s$-BuLi (2.0 mL of a $1.3 \mathrm{M}$ solution in hexanes, $2.6 \mathrm{mmol}, 1.3$ eq.) was added dropwise to a stirred solution of $N$-Boc pyrrolidine 4 (342 mg, $350 \mu \mathrm{L}, 2.0 \mathrm{mmol}$, 1.0 eq.) and (-)-sparteine 3 (607 mg, $595 \mu \mathrm{L}, 2.6 \mathrm{mmol}, 1.3$ eq.) in $\mathrm{Et}_{2} \mathrm{O}$ (7 mL) at $-78{ }^{\circ} \mathrm{C}$ under Ar. The resulting solution was stirred at $-78{ }^{\circ} \mathrm{C}$ for $1 \mathrm{~h}$. Then, benzaldehyde $(423 \mathrm{mg}, 405 \mu \mathrm{L}$, $4.0 \mathrm{mmol}, 2.0$ eq.) was added dropwise and the resulting solution was warmed to $\mathrm{rt}$ over $16 \mathrm{~h}$. Saturated $\mathrm{NH}_{4} \mathrm{Cl}_{(\mathrm{aq})}(10 \mathrm{~mL})$ was added and the layers were separated. The aqueous layer was extracted with $\mathrm{Et}_{2} \mathrm{O}(3 \mathrm{x} 10 \mathrm{~mL})$. The combined organic layers were dried $\left(\mathrm{MgSO}_{4}\right)$ and evaporated under reduced pressure to give the crude product which contained a 75:25 mixture of $(1 R, 2 R)-16$ and $(1 S, 2 R)-17$ by ${ }^{1} \mathrm{H}$ NMR spectroscopy. Purification by flash column chromatography on silica with 98:2 $\mathrm{CH}_{2} \mathrm{Cl}_{2}$-acetone as eluent gave $(1 R, 2 R)$-16 $(343 \mathrm{mg}, 62 \%$,

97:3 er by CSP-HPLC) as a colourless oil, $[\alpha]_{\mathrm{D}}-3.1$ (c 1.0 in $\left.\mathrm{CHCl}_{3}\right)\left(\right.$ lit., ${ }^{20}[\alpha]_{\mathrm{D}}-1.9(c 1.0$ in $\mathrm{CHCl}_{3}$ ) for $(1 R, 2 R)-\mathbf{1 6}$ of $\left.97: 3 \mathrm{er}\right) ; R_{\mathrm{F}}\left(98: 2 \mathrm{CH}_{2} \mathrm{Cl}_{2}\right.$-acetone) $0.4 ;{ }^{1} \mathrm{H} \mathrm{NMR}\left(400 \mathrm{MHz}, \mathrm{CDCl}_{3}\right) \delta$ 
7.39-7.25 (m, 5H, Ar), 5.93 (br s, 1H, OH), 4.53 (br d, J 8.0 Hz, 1H, CHO), 4.10 (td, J 8.0, 3.5 $\mathrm{Hz}, 1 \mathrm{H}, \mathrm{NCH}), 3.51-3.42(\mathrm{~m}, 1 \mathrm{H}, \mathrm{NCH}), 3.41-3.33(\mathrm{~m}, 1 \mathrm{H}, \mathrm{NCH}), 1.79-1.15\left(\mathrm{~m}, 2 \mathrm{H}, \mathrm{CH}_{2}\right)$, 1.14-1.45 (m, 2H, $\mathrm{CH}_{2}$ ), 1.53 (s, 9H, $\mathrm{CMe}_{3}$ ); CSP-HPLC: Chiralpak OD (98:2 hexane:iso-PrOH, $\left.0.5 \mathrm{mLmin}^{-1}\right)(R, R)-\mathbf{1 6} 24.12 \mathrm{~min},(S, S)-\mathbf{1 6} 28.85 \mathrm{~min}$ and $(1 S, 2 R)-\mathbf{1 7}(100 \mathrm{mg}, 18 \%, 97: 3$ er by CSP-HPLC) as a colourless oil, $[\alpha]_{\mathrm{D}}+75.4$ (c 1.0 in $\left.\mathrm{CHCl}_{3}\right)\left(\right.$ lit., ${ }^{20}[\alpha]_{\mathrm{D}}+95.3$ (c 1.0 in $\mathrm{CHCl}_{3}$ ) for $(1 S, 2 R)-17$ of 97:3 er); $R_{\mathrm{F}}\left(98: 2 \mathrm{CH}_{2} \mathrm{Cl}_{2}\right.$-acetone) $0.3 ;{ }^{1} \mathrm{H} \mathrm{NMR}\left(400 \mathrm{MHz}, \mathrm{CDCl}_{3}\right)(75: 25$ mixture of rotamers) $\delta 7.41-7.23(\mathrm{~m}, 5 \mathrm{H}, \mathrm{Ar}), 5.52$ (br s, $0.75 \mathrm{H}, \mathrm{OH}), 5.15$ (br s, $0.25 \mathrm{H}, \mathrm{OH}$ ), 4.87 (br s, 0.75H, CHO), 4.31 (br s, $0.75 \mathrm{H}, \mathrm{NCH}), 4.00$ (br s, $0.25 \mathrm{H}, \mathrm{CHO}), 3.56$ (br s, $0.25 \mathrm{H}$, $\mathrm{NCH}$ ), 3.30 (br s, 1H, NCH), 2.82 (br s, 0.75H, NCH), 2.51 (br s, 0.25H, NCH), 2.01-1.86 (m, $\left.1 \mathrm{H}, \mathrm{CH}_{2}\right), 1.85-1.72\left(\mathrm{~m}, 1 \mathrm{H}, \mathrm{CH}_{2}\right), 1.68\left(\mathrm{~s}, 2.25 \mathrm{H}, \mathrm{CMe}_{3}\right), 1.66-1.46\left(\mathrm{~m}, 1 \mathrm{H}, \mathrm{CH}_{2}\right), 1.52(\mathrm{~s}$, 6.75H, $\mathrm{CMe}_{3}$ ), 1.21-1.13 (m, 1H, $\mathrm{CH}_{2}$ ); CSP-HPLC: Chiralpak OD (98:2 hexane-iso-PrOH, 0.5 $\left.\mathrm{mLmin}^{-1}\right)(S, R)-1719.61 \mathrm{~min},(R, S)-1724.00 \mathrm{~min}$. Spectroscopic data consistent with those reported in the literature. ${ }^{20}$

2-(Hydroxyphenylmethyl)pyrrolidine-1-carboxylic acid tert-butyl ester $(1 R, 2 R)-16$ and (1S,2R)-17 (Table 1, entry 2). Using the general procedure, $s$-BuLi (1.65 $\mathrm{mL}$ of a $1.3 \mathrm{M}$ solution in hexanes, $2.14 \mathrm{mmol}, 1.6$ eq.), (-)-sparteine 3 (94 mg, $0.40 \mathrm{mmol}, 0.3 \mathrm{eq}$ ), bis- $i$-Prbispidine 6 (366 mg, $1.74 \mathrm{mmol}, 1.3$ eq.) and $N$-Boc pyrrolidine 4 (230 mg, $235 \mu \mathrm{L}, 1.34 \mathrm{mmol}$, 1.0 eq.) in $\mathrm{Et}_{2} \mathrm{O}(8 \mathrm{~mL})$ and then benzaldehyde $(282 \mathrm{mg}, 270 \mu \mathrm{L}, 2.68 \mathrm{mmol}, 2.0$ eq. $)$ gave the crude product. Purification by flash column chromatography on silica with $98: 2 \mathrm{CH}_{2} \mathrm{Cl}_{2}$-acetone as eluent gave $(1 R, 2 R)$-16 (221 mg, 62\%, 91:9 er by CSP-HPLC) as a colourless oil, $[\alpha]_{\mathrm{D}}-1.24$ (c 1.0 in $\mathrm{CHCl}_{3}$ and $(1 S, 2 R)-\mathbf{1 7}\left(116 \mathrm{mg}, 33 \%, 91: 9\right.$ er by CSP-HPLC) as a colourless oil, $[\alpha]_{\mathrm{D}}$ +93.0 (c 1.0 in $\mathrm{CHCl}_{3}$ ).

2-(Hydroxyphenylmethyl)pyrrolidine-1-carboxylic acid tert-butyl ester (1S,2S)-16 and (1R,2S)-17 (Table 1, entry 3). Using the general procedure, $s$-BuLi $(2.64 \mathrm{~mL}$ of a $1.3 \mathrm{M}$ solution in hexanes, $3.43 \mathrm{mmol}, 1.6$ eq.), (+)-sparteine surrogate 7 (112 mg, $0.64 \mathrm{mmol}, 0.3$ eq.), bis- $i$-Pr-bispidine 6 (585 mg, $2.78 \mathrm{mmol}, 1.3$ eq.) and $N$-Boc pyrrolidine 4 (366 mg, $375 \mu \mathrm{L}, 2.14$ mmol, 1.0 eq.) in $\mathrm{Et}_{2} \mathrm{O}$ ( $8 \mathrm{~mL}$ ) and then benzaldehyde (455 mg, $435 \mu \mathrm{L}, 4.28 \mathrm{mmol}, 2.0$ eq.) gave the crude product. Purification by flash column chromatography on silica with 98:2 $\mathrm{CH}_{2} \mathrm{Cl}_{2}$-acetone as eluent gave $(1 \mathrm{~S}, 2 \mathrm{~S})-\mathbf{1 6}(370 \mathrm{mg}, 65 \%, 94: 6$ er by CSP-HPLC) as a colourless oil, $[\alpha]_{\mathrm{D}}+0.04\left(c\right.$ 1.0 in $\left.\mathrm{CHCl}_{3}\right)$ and $(1 R, 2 S)-17(166 \mathrm{mg}, 29 \%, 94: 6$ er by CSP-HPLC) as a colourless oil, $[\alpha]_{\mathrm{D}}-106.3$ (c 1.0 in $\mathrm{CHCl}_{3}$ ).

2-(Hydroxyphenylmethyl)pyrrolidine-1-carboxylic acid tert-butyl ester $(1 R, 2 R)-16$ and (1S,2R)-17 (Table 1, entry 4). Using the general procedure, $s$-BuLi (1.06 $\mathrm{mL}$ of a $1.3 \mathrm{M}$ solution in hexanes, $1.38 \mathrm{mmol}, 1.0$ eq.), (-)-sparteine 3 (81 mg, $0.34 \mathrm{mmol}, 0.25$ eq.), bis- $i$-Prbispidine 6 (290 mg, $1.38 \mathrm{mmol}, 1.0$ eq.) and $N$-Boc pyrrolidine 4 (234 mg, $240 \mu \mathrm{L}, 1.38 \mathrm{mmol}$, 1.0 eq.) in $\mathrm{Et}_{2} \mathrm{O}(8 \mathrm{~mL})$ and then benzaldehyde $(293 \mathrm{mg}, 280 \mu \mathrm{L}, 2.76 \mathrm{mmol}, 2.0$ eq. $)$ gave the crude product. Purification by flash column chromatography on silica with $98: 2 \mathrm{CH}_{2} \mathrm{Cl}_{2}$-acetone as eluent gave $(1 R, 2 R)-16(214 \mathrm{mg}, 58 \%, 88: 12$ er by CSP-HPLC) as a colourless oil and ( $1 S$, 2R)-17 (106 mg, 29\%, 88:12 er by CSP-HPLC) as a colourless oil. 
2-(Hydroxyphenylmethyl)pyrrolidine-1-carboxylic acid tert-butyl ester (1S,2S)-16 and (1R,2S)-17 (Table 1, entry 5). Using the general procedure, $s$-BuLi $(1.13 \mathrm{~mL}$ of a $1.3 \mathrm{M}$ solution in hexanes, $1.47 \mathrm{mmol}, 1.0$ eq.), (+)-sparteine surrogate 7 (64 mg, $0.37 \mathrm{mmol}, 0.25$ eq.), bis- $i$-Pr-bispidine 6 (309 mg, $1.47 \mathrm{mmol}, 1.0$ eq.) and $N$-Boc pyrrolidine 4 (254 mg, $260 \mu \mathrm{L}, 1.47$ mmol, 1.0 eq.) in $\mathrm{Et}_{2} \mathrm{O}(8 \mathrm{~mL})$ and then benzaldehyde $(313 \mathrm{mg}, 300 \mu \mathrm{L}, 2.94 \mathrm{mmol}, 2.0$ eq.) gave the crude product. Purification by flash column chromatography on silica with 98:2 $\mathrm{CH}_{2} \mathrm{Cl}_{2}$-acetone as eluent gave $(1 S, 2 S)$-16 (220 mg, 56\%, 93:7 er by CSP-HPLC) as a colourless oil and $(1 R, 2 S)-\mathbf{1 7}(96 \mathrm{mg}, 25 \%, 93: 7$ er by CSP-HPLC) as a colourless oil.

2-(Hydroxyphenylmethyl)pyrrolidine-1-carboxylic acid tert-butyl ester $(1 R, 2 R)-16$ and $(1 S, 2 R)-17$ (Table 1, entry 6). Using the general procedure, $s$-BuLi (1.66 mL of a $1.3 \mathrm{M}$ solution in hexanes, $2.16 \mathrm{mmol}, 1.6$ eq.), (-)-sparteine 3 (95 mg, $0.41 \mathrm{mmol}, 0.3 \mathrm{eq}$.), alkene bispidine 12 (391 mg, $1.76 \mathrm{mmol}, 1.3$ eq.) and $N$-Boc pyrrolidine 4 (234 mg, $240 \mu \mathrm{L}, 1.35 \mathrm{mmol}$, 1.0 eq.) in $\mathrm{Et}_{2} \mathrm{O}(8 \mathrm{~mL})$ and then benzaldehyde $(287 \mathrm{mg}, 275 \mu \mathrm{L}, 2.70 \mathrm{mmol}, 2.0$ eq. $)$ gave the crude product. Purification by flash column chromatography on silica with $98: 2 \mathrm{CH}_{2} \mathrm{Cl}_{2}$-acetone as eluent gave $(1 R, 2 R)-16$ (220 mg, 61\%, 92:8 er by CSP-HPLC) as a colourless oil and ( $1 S$, 2R)-17 (107 mg, 30\%, 88:12 er by CSP-HPLC) as a colourless oil.

2-(Hydroxyphenylmethyl)pyrrolidine-1-carboxylic acid tert-butyl ester $(1 R, 2 R)-16$ and (1S,2R)-17 (Table 1, entry 7). Using the general procedure, $s$-BuLi (1.15 mL of a $1.3 \mathrm{M}$ solution in hexanes, $1.50 \mathrm{mmol}, 1.6$ eq.), (-)-sparteine 3 (66 mg, $0.28 \mathrm{mmol}, 0.3 \mathrm{eq}$ ), methyl bispidine 13 (274 mg, $1.22 \mathrm{mmol}, 1.3$ eq.) and $N$-Boc pyrrolidine 4 (161 mg, $165 \mu \mathrm{L}, 0.94 \mathrm{mmol}$, 1.0 eq.) in $\mathrm{Et}_{2} \mathrm{O}(8 \mathrm{~mL})$ and then benzaldehyde $(198 \mathrm{mg}, 190 \mu \mathrm{L}, 1.88 \mathrm{mmol}, 2.0$ eq.) gave the crude product. Purification by flash column chromatography on silica with $98: 2 \mathrm{CH}_{2} \mathrm{Cl}_{2}$-acetone as eluent gave $(1 R, 2 R)-\mathbf{1 6}(149 \mathrm{mg}, 60 \%, 79: 21$ er by CSP-HPLC) as a colourless oil and ( $1 S$, 2R)-17 (81 mg, 32\%, 78:22 er by CSP-HPLC) as a colourless oil.

2-(Hydroxyphenylmethyl)pyrrolidine-1-carboxylic acid tert-butyl ester $(1 R, 2 R)-16$ and $(1 S, 2 R)-17$ (Table 1, entry 8). Using the general procedure, $s$-BuLi $(1.27 \mathrm{~mL}$ of a $1.3 \mathrm{M}$ solution in hexanes, $1.63 \mathrm{mmol}, 2.9$ eq.), (-)-sparteine 3 (40 mg, $0.17 \mathrm{mmol}, 0.3$ eq.), bispidol 14 (167 mg, $0.74 \mathrm{mmol}, 1.3$ eq.) and $N$-Boc pyrrolidine 4 (98 mg, $100 \mu \mathrm{L}, 0.57 \mathrm{mmol}, 1.0$ eq.) in $\mathrm{Et}_{2} \mathrm{O}(8 \mathrm{~mL})$ and then benzaldehyde $(199 \mathrm{mg}, 190 \mu \mathrm{L}, 1.88 \mathrm{mmol}, 2.0$ eq. $)$ gave the crude product. Purification by flash column chromatography on silica with $98: 2 \mathrm{CH}_{2} \mathrm{Cl}_{2}$-acetone as eluent gave $(1 R, 2 R)-\mathbf{1 6}(82 \mathrm{mg}, 54 \%, 83: 17$ er by CSP-HPLC) as a colourless oil and $(1 S, 2 R)-17$ (47 mg, 31\%, 77:23 er by CSP-HPLC) as a colourless oil.

2-(Hydroxyphenylmethyl)pyrrolidine-1-carboxylic acid tert-butyl ester $(1 R, 2 R)-16$ and $(1 S, 2 R)-17$ (Table 1, entry 9). Using the general procedure, $s$-BuLi $(1.22 \mathrm{~mL}$ of a $1.3 \mathrm{M}$ solution in hexanes, $1.59 \mathrm{mmol}, 1.6$ eq.), (-)-sparteine 3 (70 mg, $0.30 \mathrm{mmol}, 0.3$ eq.), bis- $n$ - $\operatorname{Pr}$ bispidine 15 (271 mg, $1.29 \mathrm{mmol}, 1.3$ eq.) and $N$-Boc pyrrolidine 4 (171 mg, $175 \mu \mathrm{L}, 0.99 \mathrm{mmol}$, 1.0 eq.) in $\mathrm{Et}_{2} \mathrm{O}(8 \mathrm{~mL})$ and then benzaldehyde $(209 \mathrm{mg}, 200 \mu \mathrm{L}, 1.99 \mathrm{mmol}, 2.0$ eq.) gave the crude product. Purification by flash column chromatography on silica with $98: 2 \mathrm{CH}_{2} \mathrm{Cl}_{2}$-acetone as eluent gave $(1 R, 2 R)-\mathbf{1 6}(160 \mathrm{mg}, 61 \%, 55: 45$ er by CSP-HPLC) as a colourless oil and ( $1 S$, 2R)-17 (90 mg, 34\%, 55:45 er by CSP-HPLC) as a colourless oil. 
2-(Hydroxyphenylmethyl)pyrrolidine-1-carboxylic acid tert-butyl ester $(1 R, 2 R)-16$ and (1S,2R)-17 (Table 1, entry 10). Using the general procedure, $s$-BuLi $(0.96 \mathrm{~mL}$ of a $1.3 \mathrm{M}$ solution in hexanes, $1.25 \mathrm{mmol}, 1.6$ eq.), cyclohexane diamine $(R, R)-18$ (58 mg, $0.23 \mathrm{mmol}, 0.3$ eq.), bis-i-Pr-bispidine 6 (214 mg, $1.02 \mathrm{mmol}, 1.3$ eq.) and $N$-Boc pyrrolidine 4 (134 mg, 137 $\mu \mathrm{L}, 0.78 \mathrm{mmol}, 1.0$ eq.) in $\mathrm{Et}_{2} \mathrm{O}(8 \mathrm{~mL})$ and then benzaldehyde $(167 \mathrm{mg}, 160 \mu \mathrm{L}, 1.57 \mathrm{mmol}, 2.0$ eq.) gave the crude product. Purification by flash column chromatography on silica with 98:2 $\mathrm{CH}_{2} \mathrm{Cl}_{2}$-acetone as eluent gave $(1 R, 2 R)-16(131 \mathrm{mg}, 63 \%, 84: 16$ er by CSP-HPLC) as a colourless oil and $(1 S, 2 R)-\mathbf{1 7}(57 \mathrm{mg}, 27 \%, 85: 15$ er by CSP-HPLC) as a colourless oil.

\section{Acknowledgements}

We thank the EPSRC for a DTA award (to G.B.) and Merck for funding.

\section{References}

1. Kizirian, J.-C. Chem. Rev. 2008, 108, 140.

2. Breuning, M.; Steiner, M. Synthesis 2008, 2841.

3. Hoppe, D.; Hense, T. Angew. Chem. Int. Ed. Engl. 1997, 36, 2282.

4. Hoppe, D.; Hintze, F.; Tebben, P. Angew. Chem. Int. Ed. Engl. 1990, 29, 1422.

5. Kerrick, S. T.; Beak, P. J. Am. Chem. Soc. 1991, 113, 9708.

6. Wu, S.; Lee, S.; Beak, P. J. Am. Chem. Soc. 1996, $118,715$.

7. Stymiest, J. L.; Dutheuil, G.; Mahmood, A.; Aggarwal, V. K. Angew. Chem. Int. Ed. 2007, 46, 7491.

8. Muci, A. R.; Campos, K. R.; Evans, D. A. J. Am. Chem. Soc. 1995, 117, 9075.

9. (a) Tsukazaki, M.; Tinkl, M.; Roglans, A.; Chapell, B. J.; Taylor, N. J.; Snieckus, V. J. Am. Chem. Soc. 1996, 118, 685. (b) Metallinos, C.; Szillat, H.; Taylor, N. J.; Snieckus, V. Adv. Catal. Synth. 2003, 345, 370.

10. Kanda, K.; Endo, K.; Shibata, T. Org. Lett. 2010, 12, 1980.

11. Bailey, W. F.; Mealy, M. J. J. Am. Chem. Soc. 2000, 122, 6787.

12. Mealy, M. J.; Luderer, M. R.; Bailey, W. F.; Bech Sommer, M. J. Org. Chem. 2004, 69, 6042.

13. Beak, P.; Kerrick, S. T.; Wu, S.; Chu, J. J. Am. Chem. Soc. 1994, 116, 3231.

14. Dearden, M. J.; Firkin, C. R.; Hermet, J.-P. R.; O’Brien, P. J. Am. Chem. Soc. 2002, 124, 11870.

15. O’Brien, P. Chem. Commun. 2008, 655.

16. Stead, D.; O’Brien, P.; Sanderson, A. Org. Lett. 2008, 10, 1409.

17. McGrath, M. J.; O’Brien, P. J. Am. Chem. Soc. 2005, 127, 16378.

18. McGrath, M. J.; Bilke, J.; O’Brien, P. Chem. Commun. 2006, 2607. 
19. Bilke, J. L.; O’Brien, P. J. Org. Chem. 2008, 73, 6452.

20. Bilke, J. L.; Moore, S. P.; O’Brien, P.; Gilday, J. Org. Lett. 2009, 11, 1935.

21. Stead, D.; Carbone, G.; O’Brien, P.; Campos, K. R.; Sanderson, A. J. Am. Chem. Soc. 2010, $132,7260$.

22. Barker, G.; O’Brien, P.; Campos, K. R. Org. Lett. 2010, 12, 4176.

23. Garrison, G. L.; Berlin, K. D.; Scherlag, B. J.; Lazzara, R.; Patterson, E.; Fazekas, T.; Sangiah, S.; Chen, C.-L.; Schubot, F. D.; van der Helm, D. J. Med. Chem. 1996, 39, 2559.

24. (a) Kizirian, J-C.; Caille, J-C.; Alexakis, A. Tetrahedron. Lett. 2003, 44, 8893. (b) Kizirian, J-C.; Cabello, N.; Pinchard, L.; Caille, J-C.; Alexakis, A. Tetrahedron 2005, 61, 8939.

25. Burchat, A. F. Chong, J. M.; Nielsen, N. J. Organomet. Chem. 1997, 281. 